УДК 322.2

DOI: https://doi.org/10.26642/jen-2019-4(90)-105-117

Б.М. Андрушків, д.е.н., проф.

Тернопільський начіональний технічний університет імені Івана Пулюя

Г.М. Тарасюк, д.е.н., проф.

Державний університет «Житомирська політехніка»

Н.Б. Кирич, д.е.н., проф.

Тернопільський начіональний технічний університет імені Івана Пулюя

Ю.О. Ульянченко, д.держ.упр.

Національна академія державного управління при Президентові Украйни

А.В. Пешко, д.е.н.

підприємецьв в аграрній сфері та сфері енергоресурсів

О.Б. Погайдак, д.е.н.

Тернопільський національний технічний університет імені Івана Пулюя

\title{
На порядку денному - ринок землі: проблеми та шляхи їх вирішення
}

В умовах вступу нашої держави асочійованим членом Свропейського Союзу, залучення внутрішніх та зовнішніх інвестицій земельний чинник може стати важелем пожвавлення соціально-економічних відносини, стабільності економіки, добробуту украӥнського народу. Власне иі та інші обставини обумовлюють актуальність та своєчасність розглянутої у ичій статті проблематики.

У статті дано порівняльну характеристику земельних ресурсів України. Виявлено причини виникнення застійних явищ у реформуванні аграрного сектору економіки, техніко-економічні чинники впливу на організаційне забезпечення ефективного використання наявних засобів, трудових, матеріальних, цінових, фінансових ресурсів у цій сфері суспільного виробництва. Розкрито політичні, економічні та сочіогуманітарні особливості організації ринку землі як чинника та ресурсу забезпечення стабільності функціонування не лише переробних підприємств, а і господарської та фінансової стабільності функціонування національної економіки в цілому $i$ на иій основі досягнення стабільного розвитку суспільства.

Здійснено розробку основних заходів та принципів керування ними, систематизовано критерії та визначено показники господарсько-фінансової стійкості аграрних формувань та підприємств. Визначено вплив державної політики на розвиток реформ у сільському господарстві. Розроблено пропозиції з удосконалення системи економічних методів управління техніко-економічними чинниками на різних рівнях управління.

Ключові слова: ринок землі; агропромисловий комплекс; земля; реформи; ресурс; переробна промисловість; чинники; $Є С$.

Постановка проблеми в загальному вигляді та її зв'язок 3 практичними завданнями. Сім років тому у фахових виданнях та суспільних ЗМІ автори цієї статті за темою ринку землі підготували та опублікували цілий ряд статей. У даний час державна влада України вирішила реалізувати цей проект, та не вивчивши думки фермерів-селян, орендаторів та власників паїв і врешті науковців, рішуче приступила до розгляду його у Верховній Раді України.

Досвід приватизації промислових суб'єктів показав: благими намірами дорога до пекла стелиться. За умовами приватизації передбачалося збереження спеціалізації, робочих місць та інше, тим часом національна економіка отримала горсточку ненаситних олігархів, які, не розвинувши промислових галузей, перетворили колективні надбання, в багатьох випадках, у власну вотчину.

На даний час робиться спроба в аграрній сфері повторити це саме. Перетворити нашу землю, Великий Дар Божий, в інструментарій збагачення. Чи не наступаємо черговий раз на одні й ті ж граблі?

У статті автори застерігають від розвитку окремих негативних моментів організації цього процесу, який сьогодні поспішно відбувається здебільш волюнтарисько-провокаційними методами.

Мета отримання швидкого прибутку від реалізації землі, ленінськими словами, «чревато» перетворенням сільського населення у рабів, а маститих «покупців» у їх експлуататорів. Ми такі експерименти вже переживали... Знущання над людьми та землею завжди в історії України були причинами кровавих наслідків.

В Україні новообраним Президентом та його командою як ніколи гостро поставлено питання організації ринку землі. Без сумніву питання актуальне, своєчасне, та, враховуючи ментальність українців, посттоталітарні моменти, потребує вироблення особливих принципів та підходів у його реалізації. Нами не вперше ставиться це питання. Справа в тому, що наша держава за своїми ресурсними можливостями (маємо на увазі такий ресурс, як земля - чорнозем - гумус) потенційно може стати 
найбагатшою державою світу, бо володіє третиною цього найціннішого ресурсу планети. Справедливе та ефективне використання землі як найбільш гуманного, невичерпного, екологічно чистого, відновлювального ресурсу, та науково обгрунтоване ведення сільського господарства за повно-цикловою системою: вирощування сільгосппродукції - переробка сировини - реалізація, впровадження інноваційно-логістичних підходів, можуть зробити українців найбагатшими у світі!

В умовах вступу нашої держави асоційованим членом Свропейського Союзу, залучення внутрішніх та зовнішніх інвестицій, земельний чинник може стати важелем пожвавлення соціально-економічних відносини, стабільності економіки, добробуту українського народу тощо. Власне, ці та інші обставини обумовлюють актуальність та своєчасність розглянутої у цій статті проблематики.

Аналіз останніх досліджень та публікацій. Дослідженням різних аспектів регулювання земельних відносин займалися як зарубіжні, так і вітчизняні вчені, серед яких, Г.Бистров, П.Гайдуцький, А.Даниленко, Г.Квітка, Н.Кирич, М.Латинін, Т.Лозинська, С.Майстро, М.Малік, Т.Мостенська О.Маслак, О.Олійник, Г.Пасемко, П.Саблук, Г.Тарасюк, Ю.Ульянченко, М.Федоров, Г.Черевко, В.Шиян, В.Юрчишин та інші [1-12].

Тим часом розкриття політичних, економічних та соціогуманітарних особливостей організації ринку землі у посттоталітарних державах залишилися за полем зору зарубіжних та вітчизняних науковців. Практично не відбувається розгляд ринку землі як чинника та ресурсу забезпечення стабільності функціонування не лише переробних підприємств, а і господарської та фінансової стабільності функціонування національної економіки в цілому і на цій основі досягнення стабільного розвитку суспільства.

Мета статті. Основною метою статті визначено дослідження економічних проблем використання в Україні землі як стратегічного продукту, розкриття власне політичних, економічних та соціогуманітарних особливостей організації ринку землі в Україні.

Викладення основного матеріалу. Первинний аналіз використання у різних державах найважливіших ресурсів як чинників добробуту та стабільності економік показує різні результати. Наприклад, в Об'єднаних Арабських Еміратах таким ресурсним чинником є нафта. Не лише у Єгипті, а і арабському світі в цілому найважливішим чинником функціонування економіки теж є нафта. В Китаї розвивається промислове виробництво та сільське господарство на зрошувальних землях. У США промислове виробництво, бізнес тощо В Росії, крім нафти, на економічні відносини суттєво впливає ліс як деревний ресурс.

Цікавим у цьому аспекті $є$ Єгипет, більша частина якого розташована на околиці стародавньої Африканської пустельної платформи. До 1970-х років найважливішою статтею експорту Єгипту була бавовна, потім лідерство перейшло до нафти, яка зберігає провідну роль у національному експорті. У 1992 році частка нафти в експорті становила 51 \%. Більшість оброблюваної землі в Сгипті знаходиться в долині Нілу. Родючі алювіальні грунти разом з тривалою інсоляцією (освітлення сонячним промінням) створюють винятково сприятливі умови для вирощування різноманітних сільськогосподарських культур. Розміри традиційних селянських господарств невеликі. Приблизно дві третини всіх сільськогосподарських угідь становлять господарства по 2 га кожне. Як правило, земля належить селянину, який іiі обробляє. Багато господарств здаються в оренду, і орендар розраховується 3 власником або грошима, або в натуральній формі - частиною врожаю. Реформування сільськогосподарського сектору економіки почалося в 1986 році. У 1995 році державою контролювалися лише ціни на бавовну і цукрову тростину. Сгипет найбільш конкурентоспроможний у виробництві таких культур, як томати, пшениця, бавовна, рис, картопля, кукурудза, бобові, цукровий буряк і фрукти. Рівень самозабезпечення пшеницею до 1995 року зріс до $50 \%$.

Більшу частину Об’єднаних Арабських Еміратів займають солончаки та піщані пустелі, на заході розташовані піщані і кам'янисті пустелі, на сході і північному сході - гори Хаджар. Велика частина території ОАЕ являє собою пустельну рівнину. На сході вона переходить в кам'янисте плато (вис. до 1127 м), на півдні зливається з піщаною пустелею Руб-ель-Халі, а на заході переходить в кам'янисту пустелю Ель-Джафура. Сільське господарство становить незначний відсоток ВВП країни. 3 моменту виникнення єдиної держави уряд заохочує розвиток цієї галузі. Головна культура - пальма, культивується в основному в оазисах i на узбережжі. Вирощуються фініки й овочі. Докладаються зусилля для самозабезпечення країни зерном, але цьому перешкоджає нестача прісної води. Інтенсивний розвиток землеробства призвів до виснаження підземних водних ресурсів і засолення грунтів - кілька ферм були змушені припинити своє існування. 31979 по 1985 рік виробництво сільськогосподарської продукції зросло в шість разів. Але і на початку 1990-х років ОАЕ змушені були імпортувати близько 70 \% продовольства [3].

У сільському господарстві Північної Африки провідним є землеробство, яке залежить від штучного зрошення. Так у Лівії будують «велику штучну ріку» - водовід приблизно 1200 км, яким підземні води Сахари буде спрямовано у прибережну зону. Оброблювані площі займають 18,2 млн га - менше 5 \% території регіону. Аграрні відносини охоплюють різноманітні традиційні та сучасні форми землеробства 
й землекористування. Для особистого споживання вирощують звичайні продовольчі культури, особливо зернові, з використанням традиційних знарядь праці (мотика, плуг без відвалу). Значно поширені земельна оренда, найом безземельних і малоземельних селян-фелахів та батраків. Більшість посівних площ зайнято зерновими культурами: тверда та м'яка пшениця, кукурудза, ячмінь, рис, сорго й просо. Вирощують також бобові та цукрову тростину.

Однією 3 провідних сільськогосподарських культур східних територій регіону $\epsilon$ бавовник (вирощують цінні довговолокнисті його сорти). За виробництвом бавовни Сгипет посідає 1-ше місце в Африці (0,5 млн т), а за зборами високоякісної довговолокнистих сортів - 1-ше місце у світі.

У пустельних оазисах культивують фінікову пальму (найвищі врожаї збирають в Алжирі та Лівіі). Мавританія й Судан спеціалізуються на вирощуванні арахісу.

В Китаї, як і в сусідній Індії, найбільші в світі розміри штучно зрошуваних земель - 50-60 млн га. У Східному Китаї зараз за рахунок цього чинника годується 1,2 млрд людей, а одні й ті ж землі використовуються вже упродовж 2500 років і не виснажуються [3].

Вартість виробленої продукції зараз на 1/3 перевищує показник США і $є$ найбільшою в світі. В США один зайнятий обробляє 70 га землі, в Китаї - лише 0,3 га. В США один зайнятий годує ще 100 чоловік свого населення і країна є найбільшим у світі експортером сільськогосподарської продукції. В Китаї один зайнятий годує лише 3,5 чоловіка й експорт продукції є мінімальним.

При всіх плюсах хочемо зауважити великий ризик ведення господарства в державах, де основним економічним чинником $є$ нафта, яке значною мірою там залежить від енергозабезпечення. Наприклад, відключення енергозабезпечення (електрики) може паралізувати нафтовидобуток. Зупинка зрошування сільгоспугідь може привести до загибелі рослин тощо.

В Україні, кажуть, що перспективним для держави (інерційно) у промисловій сфері $є$ розвиток машинобудівної, авіабудівної галузі тощо. Тим часом забуваємо про такий гігантський гуманітарний ресурс, як чорнозем (гумус), який на відміну від всіх інших природних ресурсів формується тисячами і мільйонами років, є не лише життєзабезпечуючим, а й відтворюваним, перспективним, екологічним, пріоритетним, стратегічним, гуманітарним і ще можна назвати багато показників на користь цього унікального ресурсу. Він дає підстави для функціонування потужної переробної промисловості у інноваційно-логістичному ланцюзі, визначення пріоритетів та напрямів розвитку агропромислового комплексу, вирощування сільськогосподарської продукції, переробка сільгоспсировини, реалізація готової продукції тощо (рис. 1).

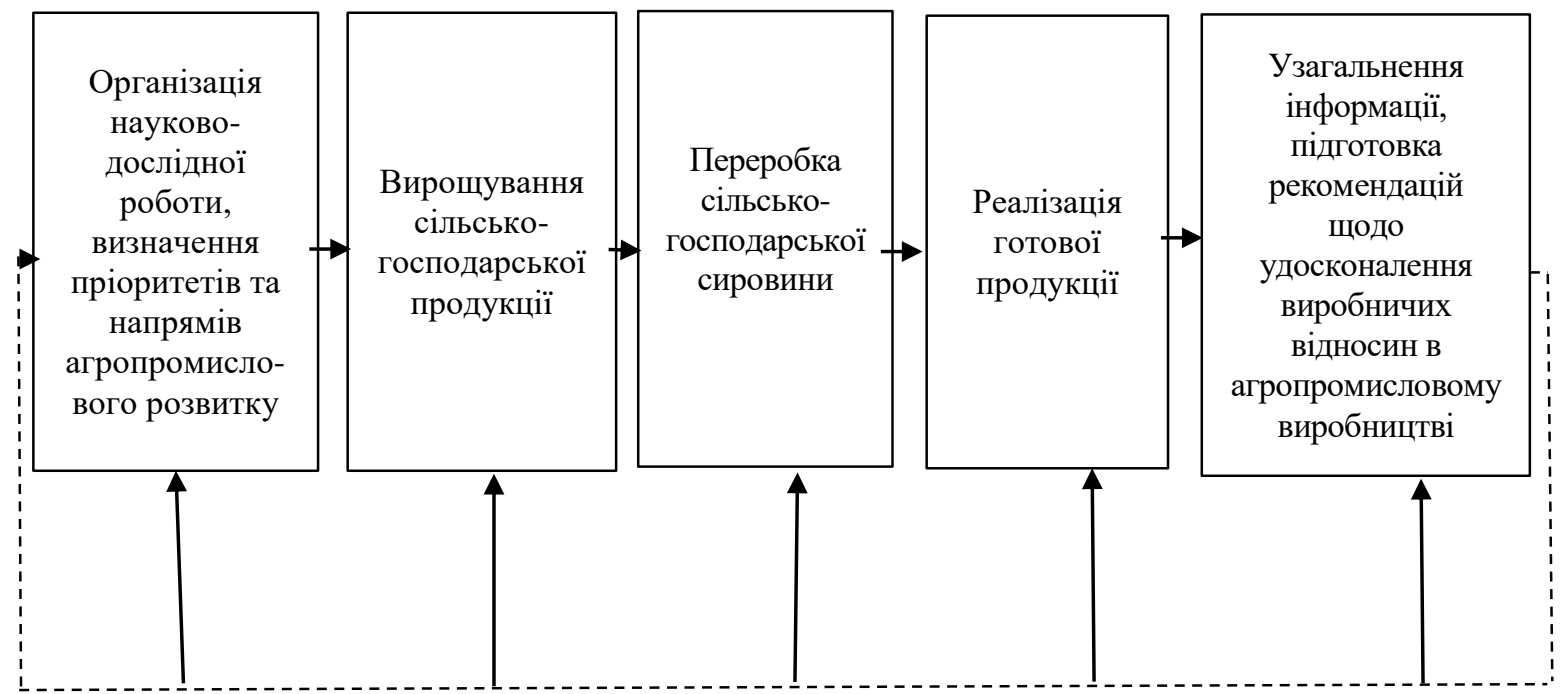

Рис. 1. Інновачійно-логістичний ланцюг організації ефективного використання земельних ресурсів

Довідково: За повідомленнями Світової Вікіпедії, більша частина території України розташована у західній частині Східноєвропейської рівнини, що займає $95 \%$ території України. Завдяки теплому клімату, гарному рельєфу (близько $60 \%$ сільськогосподарських угідь $є$ рівнинними, а ще 35 \% мають кут нахилу в діапазоні між $1^{\circ}$ та $3^{\circ}$ ) та наявності великих площ чорнозему (третина світових запасів), в Україні надзвичайно сприятливі умови для сільськогосподарського виробництва. Сільськогосподарські угіддя займають приблизно 60 \% всієї території України. Територія України поділена на три природнокліматичні зони: Полісся, Лісостеп, Степ.

Найбільш родючими грунтами не тільки в Україні, а й у світі є чорноземні. Гумусний шар в них може досягати 120 см! Про їхню родючість колись казали: «Земля така добра, що посадиш оглоблю, то виросте тарантас».

Землі, які використовуються людиною для ії потреб, утворюють земельні ресурси (земельний фонд України) (рис. 2). Вони використовуються у сільському і лісовому господарстві, на них зводяться житлові будівлі й промислові об'єкти, прокладаються транспортні шляхи. Частина земель покрита природними і штучними водоймами, які також використовуються у господарських цілях 


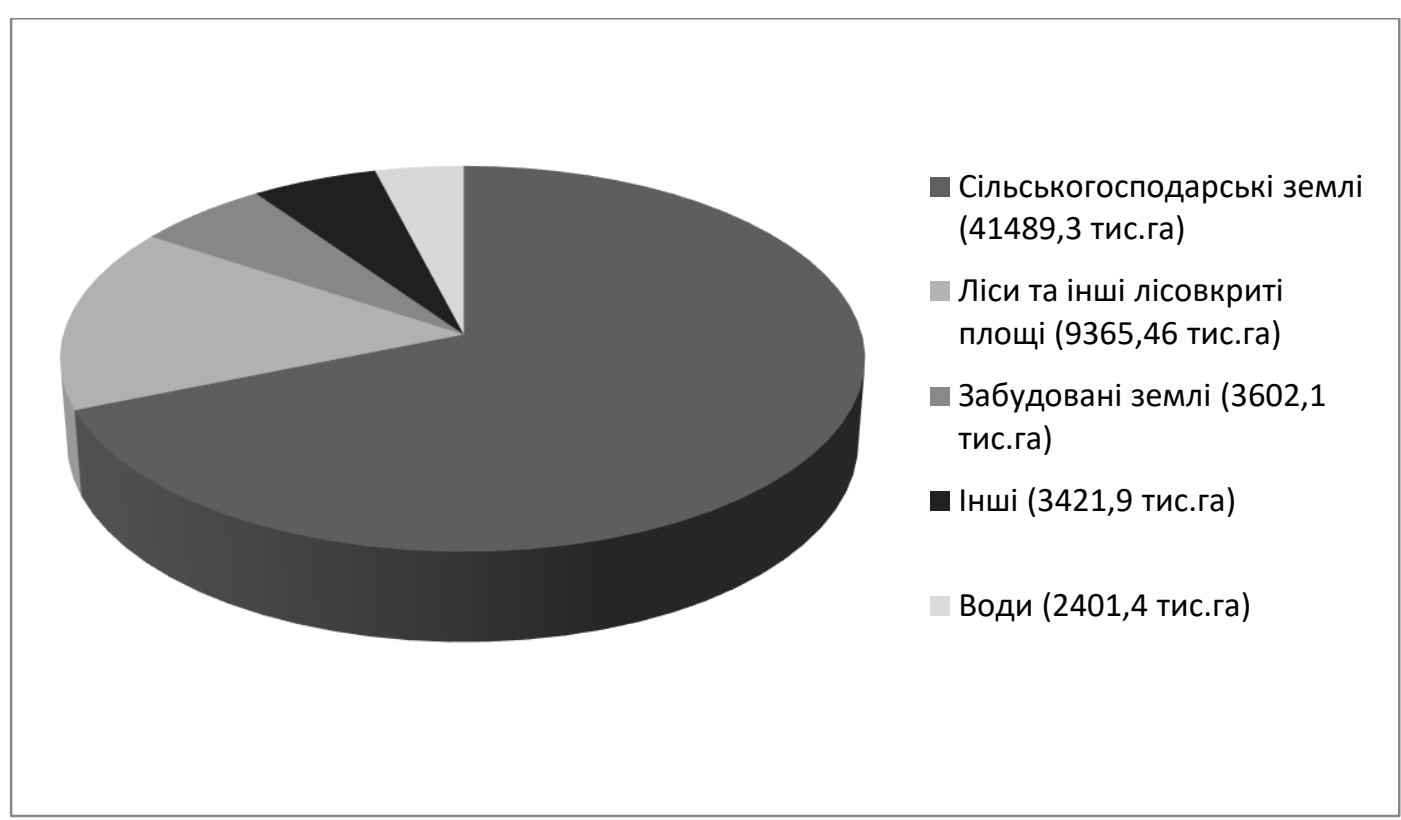

Рис. 2. Структура земельного фонду України [13]

Отже, враховуючи пострадянський досвід та специфіку політичного, соціально-економічного розвитку нашої держави, вивчивши громадську думку, можна зазначити, що доцільно зробити висновки для вироблення на цьому досвіді відповідних рекомендацій серед яких: провести соціологічні дослідження усфері земельних відносин, використавши досвід вирішення подібних проблем за кордоном в тому числі у ближньому зарубіжжі. За участі науковців та з використанням ЗМІ організувати всеобуч сільського населення та власників землі з правового забезпечення процесів приватизації. Окрім того, Уряд має ввести систему та посилити контроль в організації земельних (орендних) відносин на сучасному етапі і тим самим підтвердити спроможність держави не допустити зловживань у прийдешньому ринку землі як це мало місце в промисловій приватизації. Розробити ідеологічну концепцію розвитку держави, на цій основі посилити ідеологічне та морально-гуманітарне виховання громадян України. 3 метою створення зацікавленості в успішному розвитку вітчизняних фермерських господарств та аграрників в цілому виробити систему їх фінансово-кредитної підтримки, створити у державі сприятливий інвестиційний клімат. Передбачити наскрізну кримінальну відповідальність за зловживання у цій сфері життєдіяльності.

Для організації ринку землі та забезпечення ефективного використання земельного ресурсу в Україні як чинника підйому добробуту населення необхідно провести ряд соціально-економічних, законодавчо-правових, адміністративно-організаційних заходів та реформ. Наприклад, законодавчо забезпечити функції землі, за аналогією грошей, які є не лише засобом платежу, ціною товару, а і еквівалентом обміну тощо.

Наявність власне земельних ресурсів, їх якість та ефективне використання можуть і повинні визначати твердість національної валюти, надійність відносин, авторитет держави, забезпеченість і незалежність від державного бюрократичного апарату та інших політичних чинників громадян нашої держави. Земельний чинник може виступити важелем підняття з колін селянина як генофонду України.

Надзвичайно важливу роль на першому етапі може відіграти гуманізація кінцевих результатів сільського господарства та агропромислового виробництва загалом і зокрема виробництва екологічно чистої вирощеної на органічних добривах конкурентоздатної харчової продукції.

На Міжнародному семінарі «Органічні продукти харчування. Сучасні тенденції виробництва i маркетингу», (Львів, 31 березня 2004 р.) розглядалася актуальна проблематика сертифікації органічного сільського господарства в Україні: сучасний стан, перспективи, стратегія на майбутнє. 3 доповіддю виступив Віктор Вовк, к.ф.-м.н., директор Програми євроінтеграції та сталого розвитку Інституту громадянського суспільства, консультант з питань сталого розвитку комітетів Верховної Ради України, у якій він здійснив огляд світових тенденцій розвитку органічного сільського господарства та запропонував (3 врахуванням світового досвіду) під «органічним (екологічним) сільським господарством» розуміти агровиробничу практику, яка:

- $\quad$ не використовує синтетичних хімікатів (добрив, пестицидів, антибіотиків тощо);

- здійснює мінімальну оранку грунту;

- не застосовує генетично модифікованих організмів (ГМО) та охоплює різні сфери - не лише рослинництво, а й тваринництво, птахівництво тощо, без яких не можливе виготовлення повноцінного органічного добрива [3]. 
Органічне сільське господарство за своєю суттю є багатофункціональною агроекологічною моделлю виробництва і базується на менеджменті (плануванні й управлінні) агроекосистем. 3 метою підвищення продуктивності виробництва та якості продукції максимально використовуються біологічні чинники збільшення природної родючості грунтів, агроекологічні методи боротьби зі шкідниками і хворобами, а також переваги біорізноманіття, зокрема місцевих та унікальних видів, сортів, порід тощо.

У ширшому контексті так зване органічне сільське господарство - це практична реалізація в сфері аграрного виробництва загальної концепції «сталого, гермінативного (екологічно і соціально збалансованого) розвитку», що задовольняє харчові та промислові потреби сьогодення з урахуванням екологічних чинників. Його суспільні блага включають, зокрема:

- незалежність від промислових хімікатів, зменшення енергоємності агровиробництва, суттєве зниження виробничих витрат і залежності від зовнішнього фінансування;

- $\quad$ екологічні переваги - мінімізація негативного впливу на довкілля через запобігання деградації земель (ерозії, підвищеної кислотності, засоленості), збереження та відновлення їхньої природної родючості; припинення забруднення водних басейнів і підземних вод, очищення джерел питної води від токсичних хімікатів, зменшення викидів в атмосферу парникових газів та зв'язування вуглецю;

- збереження біорізноманіття та генетичного банку рослин і тварин, відмова від домінування монокультур, утримання тварин у наближеному до природного середовища;

- розвиток місцевих, національних та міжнародних ринків органічної продукції, сприяння справедливій міжнародній торгівлі;

- збільшення кількості робочих місць у сільській місцевості, нові перспективи для малих фермерських господарств та сільських громад, зокрема у викоріненні злиднів;

- підвищення самостійності та відповідальності аграрних виробників у процесі прийняття управлінських рішень, сприяння інноваційним сільськогосподарським дослідженням, підвищення ролі місцевих знань та ініціатив;

- $\quad$ здорові, екологічно чисті та повноцінні продукти харчування [3].

На нашу думку, вислів «ведення органічного сільського господарства» не цілком коректно відображає суть справи. За нашим переконанням вислів: «вирощування екологічно чистої продукції 3 використанням органічних добрив» $є$ більш точним. Враховуючи використання попередніх термінів у відносинах з зарубіжними партнерами, ми і надалі, тимчасово, у цій статті будемо його використовувати.

Світова практика екологічно чистого аграрного виробництва в умовах ринку землі вимагає інвестицій та впровадження прогресивних технологій. На сьогодні під органічне сільське господарство в світі виділяються великі площі земель: в Свропі - 5,1 млн га, Північній Америці - 1,5 млн га, Латинській Америці - 4,7 млн га, а в Австралії - цілих 10,6 млн га. В Свропі частка земель, переведених на органічне землеробство, значно зросла за останні роки, чому сприяла започаткована в 1993 році спільна політика ЄС щодо підтримки фермерів у перші роки після переходу від звичайного до органічного агровиробництва: середній показник у країнах ЄС досяг близько 4 \%, в Австрії та Італії він сягнув 8 \%, а в Швеції, яка є європейським лідером, - майже 12 \%. У Швейцарії частка таких земель також є однією 3 найбільших - понад $10 \%$ [3].

Ситуація на світових ринках продовольства свідчить про зростаючу зацікавленість споживачів у здоровому та повноцінному харчуванні разом з безпосереднім внеском у збереження природного довкілля. В багатьох країнах світу, передусім у США та СС, вже діють ринки органічної сільськогосподарської продукції та харчових продуктів, а також створена й успішно функціонує відповідна інфраструктура сертифікації, маркетингу і реалізації. Мотивація споживачів продукції, вирощеної на органічних екологічно чистих добривах, поєднує такі вимоги та очікування:

- здорове та екологічно безпечне харчування;

- $\quad$ вищі смакові якості;

- $\quad$ збереження природного середовища в процесі виробництва;

- не містить у собі генетично модифікованих організмів;

- в'язок з виробником - місцевий чи регіональний, або навіть прямий;

- $\quad$ висока якість продуктів та їхня свіжість.

Соціальні методи дослідження (опитування) показали, така мотивація зумовлює готовність частини споживачів платити додаткову премію (10-50 \% від звичайної ціни) за органічні продукти харчування й попит на них у світі швидко зростає. Світовий ринок органічної продукції оцінюється в 23-25 млрд дол. США, зокрема в США - 11-13 млрд та Європі - 10-11 млрд дол. США, а середній темп його зростання складає близько 10-15 \%. За найбільш загальними показниками у 2005 році цей ринок може сягнути 2931 млрд дол. США. За споживанням органічних продуктів харчування на душу населення світовим лідером є Швейцарія, кожен житель якої в середньому витрачає на них 117 дол. США на рік, до неї наближається Данія з сумою в 73 дол. Цей показник у більшості країн ЄС нині складає 30-50 дол. на рік, а в США - 45 дол., і має тенденцію до швидкого зростання. 
Нині в світі майже сформувалися повноцінні ринки продукції, вирощеної на органічних, екологічно чистих добривах, в таких сегментах, як овочі та фрукти, дитяче харчування, сільськогосподарська сировина для переробки (передусім зерна) та молочні продукти, а тому темпи зростання в них дещо сповільнилися. Подальше зростання ринків органічної продукції відкриває можливості для виходу на них нових виробників. Так ЄС і Швейцарія є імпортерами, в тому числі зі Східної Свропи, зерна, насіння олійних культур, овочів і фруктів та яловичини, вирощених за органічною системою. Водночас для убезпечення від нестабільності та експортних ризиків на цих нових ринках дуже важливим $\epsilon$ також розвиток внутрішнього ринку органічних продуктів харчування.

Україна має великий потенціал для виробництва так званої органічної сільськогосподарської продукції та її реалізації шляхом експорту, а також у середньостроковій перспективі для ії постачання на внутрішній ринок. Водночас органічне сільське господарство сприятиме вирішенню низки актуальних проблем, які існують в аграрному виробництві України та їі сільських районах. Обстеження на початку незалежності засвідчили, що в цілому до 90 \% орної землі в Україні зазнали різного ступеня деградації, яка призводить до скорочення ii продуктивності: близько 35,8 \% земель еродовані, 25,6 \% мають підвищену кислотність, 9,7 \% засолені й солонцюваті, а 8,9 \% перезволожені та заболочені. 3 іншого боку, внаслідок економічної кризи, зокрема через брак обігових коштів, за останні роки значно зменшилося використання мінеральних добрив, пестицидів та інших хімікатів, а отже, призупинилася втрата природної родючості грунтів. На сьогодні існують значні площі екологічно чистих чорноземів, які можуть бути переведені на органічне землеробство протягом відносно короткого перехідного періоду.

Самі принципи органічного сільського господарства давно відомі в Україні завдяки розвитку концепції «біологічного землеробства», що забезпечує науково-фаховий потенціал, здатний швидко засвоїти міжнародні спеціальні стандарти, в тому числі адаптувати їх до української специфіки та реалізувати їх на практиці. А деякі передові агропідприємства, наприклад агрофірма «Обрій» (Полтавська область) та інші, фактично здійснюють сільськогосподарське виробництво у такий спосіб, що може дозволити сертифікацію їхньої продукції як органічної. Окремі фермерські господарства в деяких регіонах України вже задіяні у виробництві органічної продукції та мають досвід іiі експорту завдяки сертифікації, яка проводиться іноземними сертифікаційними установами.

В Україні вже існує категорія людей (до 5 \% населення), передусім у великих містах, які мають зазначену мотивацію до споживання органічних продуктів і готові платити за них вищу ціну. Ця група споживачів створює початкову нішу для органічної продукції в Україні, а отже, для формування внутрішнього ринку такої продукції.

За умови належного впровадження сучасних агроекологічних технологій подальшому розвитку внутрішнього ринку в Україні в середньостроковій перспективі сприятиме зростання конкурентноздатності органічної продукції, яке відбуватиметься шляхом:

- $\quad$ поступового зростання природної продуктивності органічного аграрного виробництва;

- суттєвого зниження виробничих витрат - відмови від застосування дорогих хімікатів та зменшення енергоємності виробництва, зокрема мінімізації потреб у пальному;

- підвищення самодостатності та скорочення залежності виробників від невигідних умов зовнішнього фінансування - банківських кредитів тощо і виплат з них.

Нарешті, як ми зауважували, досвід розвитку органічного сільського господарства у світі свідчить про створення додаткових робочих місць у сільській місцевості й нових перспектив для малих фермерських господарств і життєздатності сільських громад та інші соціальні переваги, які $\epsilon$ надзвичайно актуальними для України.

Для функціонування світових ринків органічної продукції та розвитку органічного сільського господарства надзвичайно велику роль відіграє гарантійна система, яка включає певні стандарти, а також установи з інспекції та сертифікації. Ця система забезпечує відповідність органічним стандартам усього процесу аграрного виробництва та переробки сільськогосподарської сировини до рівня кінцевої продукції, включно з ії упаковкою та маркуванням. Таким чином, сертифікація органічної продукції спрямована на методи й засоби як сільськогосподарського виробництва, так і переробки сировини, виготовлення харчових продуктів та їхню доставку до споживача.

В основу тієї чи іншої сертифікації органічної продукції кладуться бізнесові стандарти та/або правові норми. Стандарти є добровільними угодами - результатом досягнення певного консенсусу споживачів та виробників товарів i послуг, тоді як правові норми встановлюють обов'язкові вимоги, які використовуються для державного регулювання. Змішаним варіантом є державне регулювання, яке базується на бізнесових стандартах. У сучасному світі переважає тенденція до заміни правових норм щодо органічної продукції стандартами, оскільки останні - простіші у застосуванні та легше піддаються міжнародній гармонізації, а також через політику дерегулювання, яка здійснюється в багатьох країнах.

Провідну роль у формуванні стандартів та міжнародній акредитації установ, які займаються сертифікацією органічної продукції на відповідність цим стандартам, відіграє Міжнародна федерація органічного сільського господарства (IFOAM) - міжнародна неурядова організація, яка поєднує понад 
700 активних організацій-учасників у близько 100 країнах світу. Ще в 1980 році федерація сформулювала перші «Базові стандарти IFОАМ щодо органічного виробництва та переробки», а згодом почала здійснювати оцінку сертифікаційних установ на врахування ними зазначених базових стандартів, використовуючи для цього розроблений нею «Акредитаційний критерій IFOAM» $[1,3]$.

Сьогодні ці базові стандарти та акредитаційний критерій, які були вдосконалені в результаті тривалих та інтенсивних консультацій, широко визнані в світі, зокрема зареєстровані як «міжнародні стандарти ISO». Базові стандарти IFOAM фактично виконують функцію «стандартів для стандартів», дозволяючи різні варіації, і тому покладені в основу як багатьох стандартів у приватному секторі, так i державного регулювання в різних країнах, зокрема Директиви СС 2092/91.

Міжнародна федерація має програму добровільної міжнародної акредитації сертифікаційних установ як членів IFOAM, так і установ, які не входять до числа ії членів. Акредитація, побудована на базових стандартах й акредитаційному критерії IFOAM, проводиться незалежною компанією IOAS, заснованою федерацією. На сьогодні в IOAS вже акредитовано або знаходяться в процесі акредитації 29 сертифікаційних установ зі США, Європи, Японії, Австралії, Китаю, країн Латинської Америки та ін., на які припадає близько 50-60 \% світового обсягу сертифікаційних послуг. Між акредитованими IOAS установами діє багатостороння угода, а також двосторонні угоди, які забезпечують взаємне визнання їхніх сертифікацій [5].

В Свропейському Союзі державне регулювання в сфері органічної продукції здійснюється за допомогою Директиви СС 2092/91, яка, зокрема:

- $\quad$ визначила загальні межі та принципи органічного сільського господарства, вимоги до процесу виробництва сільськогосподарської продукції, ії переробки та виготовлення харчових продуктів, ознаки та маркування органічної продукції;

- скасувала національне регулювання і створила єдиний ринок органічної продукції;

- започаткувала систему інспекції/контролю органічної продукції, в тому числі при її імпорті в країни ЄС;

- відкрила ринок органічної продукції в СС для імпорту з «третіх країн».

Система інспекції органічної продукції в ЄС є змішаною - державно-приватною. Для загального відома Державні органи в країнах ЄC уповноважені здійснювати акредитацію приватних сертифікаційних установ та нагляд за їхнью діяльністю. В свою чергу, ці установи контролюють фермерські господарства, харчову промисловість й імпортерів 3 інших країн, а також сертифікують їхню продукцію відповідно до тих чи інших бізнесових стандартів, які мають відповідати вимогам законодавства СС (фактично базовим стандартам IFOAM). Експорт органічної продукції до ЄC з інших країн передбачає обов'язкову наявність сертифіката, виданого сертифікаційною установою, акредитованою в СС [6].

Існуючі відмінності в державному регулюванні органічного сільського господарства різних країн, а також у приватних стандартах стримують зростання світових ринків органічної продукції та створюють перешкоди в торгівлі нею. Програма акредитації сертифікаційних установ, яку здійснює IFOAM, дозволяє досягти міжнародної гармонізації базових вимог до органічної продукції. Водночас лише покупці та споживачі органічної продукції можуть визначати, яким конкретним бізнесовим стандартам вони віддають перевагу, і тільки вони можуть приймати рішення, якій саме сертифікації вони довіряють.

Використання розробок IFOAM як основи для державного регулювання органічної продукції в певній країні дозволяє вирішити проблему міжнародної узгодженості, суттєво спрощує національне законодавство, заощаджує ресурси і кошти та дозволяє уникнути багатьох перешкод для виробників. Можливими варіантами цього $€$ включення до законодавства посилань на базові стандарти та акредитаційний критерій IFOAM, визнання акредитації IFOAM для роботи сертифікаційних установ в країні, а також використання послуг IOAS національними сертифікаційними установами.

В Україні існує не лише певний інтерес до розвитку екологічно чистого сільського господарства, яке нині знаходиться лише у початковій формі, а і реальні можливості. В цьому контексті надійна система інспекції та сертифікації органічної продукції є стратегічно важливим чинником як для іiі експорту 3 України вже в найближчому майбутньому, так і для розвитку внутрішнього ринку такої продукції, який $\epsilon$ реальним у середньостроковій перспективі. Створення ж української системи сертифікації, яка буде визнаною на національному та міжнародному рівнях, суттєво сприяло б широкому впровадженню органічного аграрного виробництва в Україні.

Водночас ринком землі диктуються об'єктивні інституційно-правові, фінансово-економічні та соціально-психологічні проблеми, політичні та морально-етичні моменти які створюють перешкоди та вимагають їх вирішення серед яких:

- відсутність законодавчої бази, зокрема базового закону щодо органічного сільського господарства та сертифікації органічної продукції;

- необхідність створення інституційної інфраструктури, передусім сертифікаційних установ, асоціацій виробників органічної продукції та відповідної торгівельної мережі; потреба в інтеграції в існуючі міжнародні структури для полегшення доступу на зовнішні ринки; брак інформаційноконсультаційного забезпечення та компетентних дорадчих служб; 
- $\quad$ відсутність державної підтримки на період переходу до органічного агровиробництва; можливі фінансові втрати під час конверсії та зміни кон’юнктури ринку; додаткові витрати на технічне переобладнання;

- необхідність зміни стереотипів; брак екологічного мислення та освіти; інноваційна пасивність управлінських структур; високий рівень бідності населення.

Для визначення та реалізації наступних кроків доцільно буде сформувати широке партнерство, яке єднатиме інтереси та потреби різних зацікавлених сторін в Україні, а також залучить до активної співпраці:

- сільськогосподарських виробників, зокрема фермерські господарства та їхні асоціації;

- державні органи влади і управління;

- приватні консультаційні компанії та сертифікаційні установи;

- організації споживачів;

- наукові установи та громадські організації.

Розвиток органічного сільського господарства та створення відповідної системи сертифікації в Україні потребуватиме кваліфікованих спеціалістів, ефективних інститутів та сучасної законодавчої бази, яка враховуватиме світові та європейські тенденції. В цьому контексті доцільним та дуже корисним може стати використання багатого досвіду й інструментарію, які Україна може запозичити у Міжнародної федерації органічного сільського господарства IFOAM, Свропейського Союзу, а також у країн-лідерів, зокрема Швейцарії.

Особливою місією організації ринку землі є визначення иї ціни, основних їі функцій та чинників, що на неї впливають.

В ринковій економіці всі відносини між людьми опосередковуються товарно-грошовими формами, все практично є об'єктом купівлі-продажу і має свою ціну. 3 допомогою цін виражаються різні показники і вимірюються економічні величини: обсяги виробництва, обігу і споживання, основні i оборотні фонди та інші ресурси. Отже, в першу чергу, ціни - це форма вираження економічних (мінових) відносин людей в умовах товарної економіки, тобто категорія суспільна. По-друге, ціна на конкретний товар може бути вищою або нижчою, тобто може коливатися. Але ці коливання не є довільними, вони відбуваються навколо внутрішньої субстанції ціни, якою $є$ вартість товару. Тому ціна як категорія кількісна - це грошове вираження вартості товару.

Проблема ціноутворення, визначення факторів, що формують ціну, впливають на ії рівень - одна 3 центральних проблем економічної теорії. Це знайшло своє відображення у численних теоріях, присвячених вартості і цінам в т. ч. і в сільському господарстві. Вартість - це втілена в товари праця. Причому, праця не кожного індивідуального приватного виробника, а суспільно-необхідна. Тобто праця, яка відображає середні умови виробництва даного виду товару, на даному етапі розвитку суспільства, в даних конкретних умовах. Затрачена на виробництво товару чи послуги праця сама в собі виразитися не може, тому що в загальному виразі - це затрати фізичної, розумової та нервової енергії людини, яку вона витрачає, виробляючи блага. Тому формою виразу вартості $€$ мінова вартість, тобто певна кількісна пропорція, в якій один товар обмінюється на інший [6]. Вартість лежить в основі будь-якого обміну, регулює пропорції, в яких товари чи послуги обмінюються на ринку. Історично процес розвитку форми прояву вартості пройшов досить складний і тривалий шлях - від простої (випадкової) форми до грошової. 3 появою грошей виникає ціна як грошовий вираз вартості, якою люди користуються і в сучасній ринковій економіці. Виступаючи грошовим виразом вартості, ціна не обов'язково повинна дорівнювати їй. Більше того, в реальних мінових відносинах ціна практично завжди відхиляється від вартості, може бути вищою або нижчою вартості. Це коливання зумовлено певними факторами, про які мова піде далі.

Визначення рівня цін витратами виробництва вилучає 3 цього процесу вартість додаткового продукту, який є важливим елементом вартості, а отже, і ціни. Згідно теорії трьох факторів, у створені благ (товарів) беруть участь три чинники виробництва: праця, капітал (засоби виробництва) і земля. Ціною цих виробничих факторів є заробітна плата, процент (прибуток) i рента, які відповідно розподіляються між власниками факторів робітниками, власниками засобів виробництва (капіталістами) i земельними власниками. Ціна названих факторів формує субстанцію (основу) вартості, яка у грошовому вираженні виступає як ціна товару. Отже, певна тавтологія, або спроба вивести ціну з ціни, що притаманно теорії витрат виробництва, зберігається і в теорії трьох факторів виробництва. Але незважаючи на це, вона послужила основою багатьох наступних теорій ціноутворення, зокрема теорії граничної корисності, яка отримала широкий розвиток зі 70-х років. Суть цих теорій зводиться до наступного:

а) в процесі ринкової взаємодії попиту і пропозиції, що визначає рівень ринкових цін, вирішальне значення належить попиту;

б) вартість розглядається як суб'єктивна категорія, результат оцінки індивідуумом споживчих благ залежно від інтенсивності потреб і рідкості благ;

в) суб'єктивна оцінка визначається, виходячи з граничної корисності останньої одиниці товару, що задовольняє дану потребу.

Отже, вирішальне значення надається сфері обігу, де вступають у взаємодію індивідуальні оцінки покупців і продавців. Виробництву відводиться другорядна роль. 
При всій однобічності (утворення вартості лише у сфері обігу) теорії граничної корисності відіграли певну роль у розвитку економічної теорії, а саме - у розкритті закономірностей прояву корисності i формування ринкового попиту. Використовуються вони і для аналізу динаміки і оптимізації економічних процесів ринкової економіки, для математичного моделювання, при прийнятті економічних рішень, пов'язаних з альтернативним вибором між можливими варіантами. Близькою за суттю до теорії граничної корисності є теорія попиту і пропозиції. Тим часом вона не враховує той факт, що самі попит і пропозиція залежать від цін товарів. Найбільше впливає на сучасні теорії вартості і цін неокласична теорія англійського економіста кінця XIX початку XX ст. А.Маршалла. Вона поєднує теорію витрат виробництва, граничної корисності, попиту і пропозиції у формуванні і русі цін. Виходячи 3 того, що формування ринкових цін відбувається в результаті взаємодії попиту і пропозиції, А.Маршалл пов'язував зміни попиту 3 категорією граничної корисності, а пропозиції - з вирішальним впливом витрат виробництва.

У сучасних теоріях ціноутворення переважає підхід, згідно 3 яким теорія вартості вже не займає центрального місця. На передній план вийшла теорія ціни, яка комплексно вивчає вплив різноманітних ціноутворюючих факторів, що впливають на ціни посередництвом зміни попиту і пропозиції на ринках. Деякі економісти, виходячи з того, що ціна в сучасному виробництві залежить від складного комплексу факторів (продуктивність праці, циклічний характер виробництва, стан грошового обігу, характер державного регулювання тощо), висловлюються взагалі проти необхідності використання будь-якої теорії вартості. Це стосується насамперед мікроекономічного аспекту ціноутворення.

Ціна як основний інструмент ринкового механізму виконує найрізноманітніші функції. В економічній літературі, залежно від того на якому рівні (макро- чи мікро-) ціна розглядається, які критерії беруться за основу, зустрічаються різні типи класифікації цих функцій, називається їх різна кількість. Не заперечуючи значущості інших класифікацій, ми дотримуємося точки зору, що критерієм виокремлення функцій ціни має бути 3'ясування iї ролі як основного інструменту, який опосередковує функціонування усього ринкового механізму. Виходячи 3 цього, можна вирізнити три найбільш важливі функції ціни: обліково-інформаційну, розподільчу та стимулюючу. Основною функцією ціни можна вважати обліково-інформативну. Ціна, як нам відомо, це грошовий вираз вартості. Отже, чим повніше вона відображає вартість (суспільно-необхідні затрати), тим надійніше їі можна використовувати для порівняння затрат, зіставлення ефективності різних господарських рішень, визначення свого місця в ринковій конкуренції тощо.

Отже, по-перше, виконання цієї функції цінами полягає у максимальному наближенні їх до суспільно-необхідних затрат, забезпеченні покриття витрат виробництва і обігу, а також певного прибутку державі, фірмі і окремому підприємцю. По-друге, ціни, завдяки тому, що дають інформацію про попит на товари (послуги), вигідність їх виробництва, слугують надійним інструментом для економічних вимірів, вибору економічних видів продукції і напрямків технічного прогресу, прийняття оптимальних, з точки зору суспільства, фірми, окремого підприємця оперативних та стратегічних господарських рішень. По-третє, виконуючи цю функцію, ціна у ринковій економіці сприяє координації зусиль мільйонів організацій, фірм і індивідів, які складають національне господарство. Така координація вимагає колосальної інформації про наявність найрізноманітніших товарів і послуг, які пропонуються величезній кількості економічних суб'єктів. До того ж, останні повинні мати цілком чіткі спонукальні мотиви, передбаченим чином реагувати на ту інформацію, яка отримується, і передавати іiі далі. Саме таку інформацію і спонукальні мотиви містять в собі ціни. Завдяки розподільчій функції ціни сприяють розподілу і перерозподілу вартості суспільного продукту і національного доходу, в результаті чого покриваються затрати на виробництво, утворюються доходи і нагромадження у державі, галузях, регіонах, на підприємствах (фірмах), а також у окремих соціальних груп населення і індивідів. Від зміни цін суттєво залежить, які господарюючі суб’єкти збільшать свої доходи, а які зменшать, збільшиться чи зменшиться майнова диференціація населення, буде нормальною чи порушиться еквівалентність обміну між галузями і сферами народного господарства, регіонами, підприємствами, індивідами і державами. Чим складнішим і масштабнішим стає ринкове господарство, тим активнішу роль у формуванні розподільчої функції ціни починає відігравати держава. Про що мова піде далі. Ціни активно впливають на виробництво продукції та іiі виробниче і особисте споживання. При одних цінах господарюючий суб'єкт буде прагнути швидше засвоювати виробництво нової, прогресивної продукції, а при інших - він буде байдужим до неї. Аналогічно веде себе і споживач. Стимулюючий або антистимулюючий вплив ціна здійснює на виробника шляхом збільшення або зменшення прибутку при реалізації товару (послуги), а на споживача - більш високим або нижчим своїм рівнем. Так ціни заохочують виробників, при збільшенні ними випуску і реалізації продукції шляхом зростання маси прибутку. Стосовно споживачів стимулююча функція ціни проявляється у зворотній залежності: ціни зросли - купівля i споживання продукції споживачами зменшилася і навпаки.

Визначення ціни як грошового виразу вартості не означає, що ціна обов'язково збігається з вартістю. Більше того, їх збіг можна розглядати лише як епізод, як тимчасове явище. Реальна ринкова ціна, як правило, вища або нижча вартості. І ці коливання ціни навколо вартості відбуваються під впливом різних факторів. їх можна звести у дві такі групи: ціноутворюючі фактори і фактори ціновідхиляючі. 
Ціноутворюючі чинники, це ті чинники, що діють у сфері виробництва. Вони впливають на величину затрат на виробництво товару чи послуги, а отже, формують основу ціни. До них належать всі фактори, які впливають на продуктивну силу праці. Ціновідхиляючі - це фактори, що діють на ринку. Вони сприяють відхиленню ціни від уже сформованих у процесі виробництва затрат праці (рис. 3).

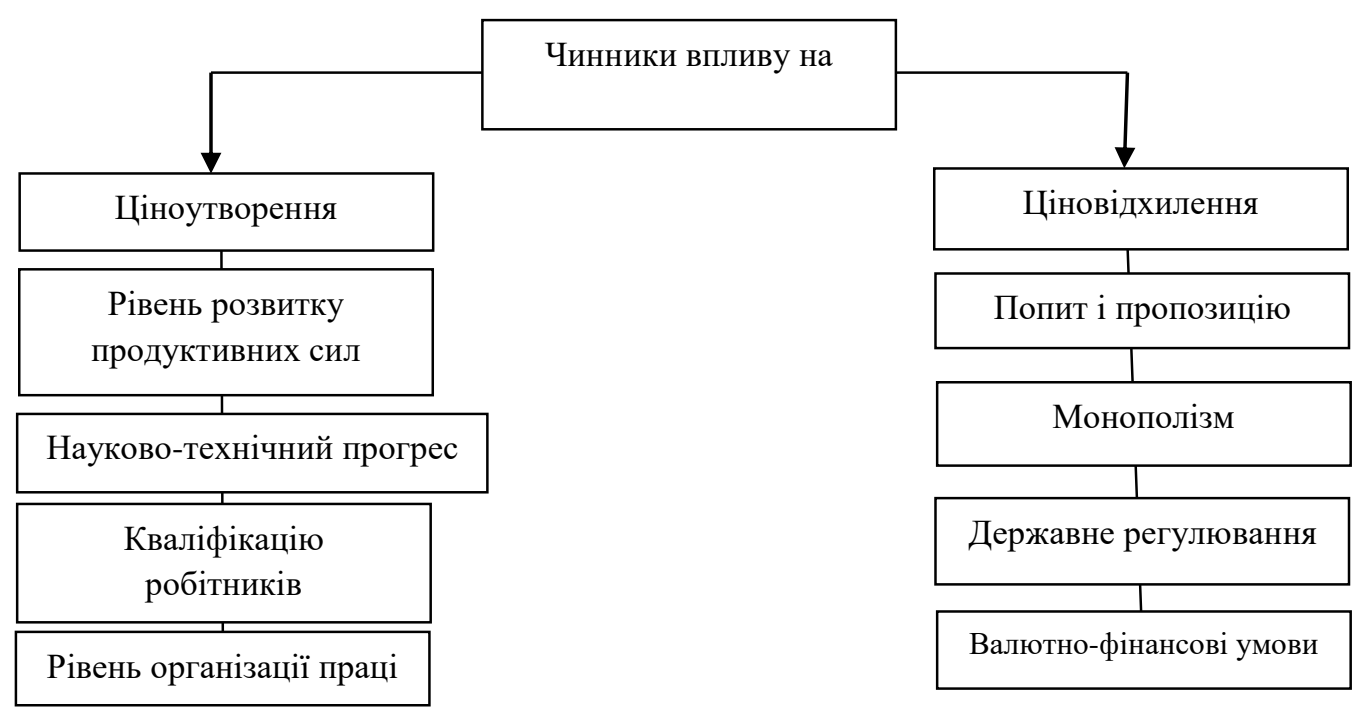

Рис. 3. Чинники, щ̧о впливають на рівень цฺін

Таким чином, формуючи ціну землі, необхідно враховувати всі теоретичні надбання у цій сфері, функції та чинники, що впливають на неї. Як було зауважено, шляхи впровадження реформаційнотрансформаційних змін у сфері використання земельних ресурсів мають передбачати:

- $\quad$ законодавче забезпечення всіх процесів у формі створення і затвердження у законодавчому порядку Економічної Конституції України;

- впровадження повного господарського регіонального розрахунку.

Реалізацію проекту «Розвиток «Колосу України» можна представити на рисунку 4.

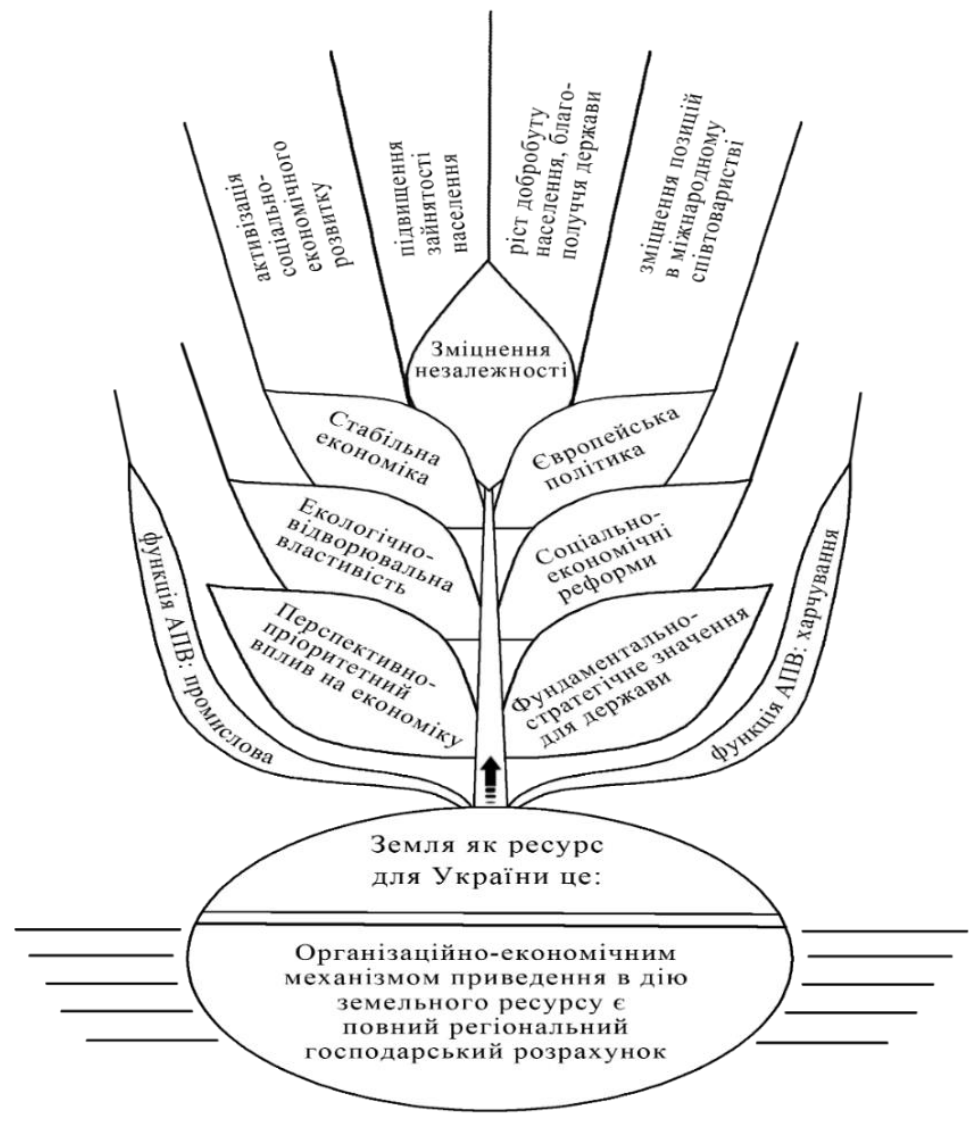

Рис. 4. Розвиток «Колосу Украӥни» в умовах СС 
Висновки та перспективи подальших досліджень. Таким чином, маємо право зробити такі висновки. Не гафній, не уран, сірководень, не граніт, марганець та інше роблять нашу державу багатою, а само відтворюваний ресурс - земля! Тим часом селянин, за діями олігархату, розмірковує, що забрати землю у нього не потрібно прикладати багато зусиль, лише витримати декілька умов:

- на регіональному рівні не дати засобів і вигідних позик та кредитів для їх придбання; не створити страхових та інших умов для іiі обробітку. Тим самим підтвердити чи довести, що селянин не може ефективно іiі використовувати. Благо - ефективний (одинак) господарник іншими словами куркуль системно винищений попереднім режимом;

- без розумних роз'яснень населенню (умов та особливостей проведення заходу) розпочати адміністративно-територіальну реформу у якій заховати чи загубити всі кінці всіх процесів;

- на рівні держави безконтрольно набрати за кордоном розмаїтих кредитів, позик, безнадійних інвестицій та на стільки, щоб їх обсяги створили передумови, за яких не залишиться іншого шляху як розраховуватися ресурсами в тому числі і землею.

Якщо селянин буде опиратися продажу, є такий важіль як податки. Вони і повинні його бідолаху зламати, та змусити відмовитись від... свого.

Близько 70 \% земельного фонду України - це сільськогосподарські угіддя, більшість 3 яких зосереджені на родючих грунтах і дуже за період тоталітарного режиму розорані. Орні землі (або рілля) становлять 4/5 від загальної площі сільськогосподарських угідь - це один із найвищих показників у світі. Забезпеченість одного мешканця країни ріллею перевищує світовий і європейський показники майже у 2,5 раза. Найвища частка ріллі у степовій зоні - близько 90 \%. Проте така висока розораність земель нерідко призводить до посилення водної та вітрової ерозії грунту - знесення родючого шару. Внаслідок цього виникають яри та балки, трапляються пилові бурі. Великої шкоди грунтам завдають неправильний обробіток, безсистемні зрошування і внесення мінеральних добрив. Внаслідок цього грунти руйнуються та виснажуються, знижується їх родючість.

Для підтримання грунтів у належному стані необхідно вживати різні заходи: насаджувати дерева і кущі на схилах ярів, щоб зупинити їх ріст; схили височин розорювати упоперек, щоб запобігти змиванню грунту поверхневими водами; в міру зрошувати землі; науково обгрунтовано вносити мінеральні добрива.

В цілому впровадження інноваційно-логістичних підходів, залучення внутрішніх та зовнішніх (в умовах СС) інвестицій дозволяє на базі активізації використання земельних ресурсів розвивати не лише різноманітні галузі сільського господарства, а передусім переробну промисловість за замкнутим циклом від вирощування сільгосппродукції до ії переробки та реалізації. Враховуючи пострадянський досвід та специфіку політичного й соціально-економічного розвитку нашої держави, результати приватизації у промисловому секторі економіки та зокрема у плані збереження спеціалізації підприємств, робочих місць, ліквідації фондів їх розвитку тощо. На нашу думку, з метою повернення довіри населення до влади, уряд повинен:

1. Провести соціологічні дослідження та вивчити громадську думку у сфері земельних відносин, використавши досвід вирішення подібних проблем за кордоном.

2. За участі науковців та 3 використанням 3МI організувати всеобуч сільського населення та власників землі з правового забезпечення процесів приватизації землі.

3. 3 метою забезпечення повноциклового агропромислового виробництва створити сприятливі умови для розвитку сільськогосподарського машинобудування.

4. Ввести систему, навести порядок та посилити контроль в організації земельних (орендних) відносин на сучасному етапі і тим самим підтвердити спроможність держави не допустити зловживань у прийдешньому ринку землі. На даний час існують договірні відносини на принизливих умовах для власників землі.

5. Розробити ідеологічну концепцію розвитку держави, на цій основі посилити ідеологічне та морально-гуманітарне виховання громадян України.

6. Запропонувати моральний кодекс покупця землі (в історії України була традиція особливого довір'я бджоловодам).

7. 3 метою створення зацікавленості в успішному розвитку вітчизняних фермерських господарств та аграрників в цілому виробити систему їх фінансово-кредитної підтримки, створити у державі сприятливий інвестиційний клімат.

8. Передбачити кримінальну відповідальність за зловживання у цій сфері життєдіяльності.

При ігноруванні цих принципів, процес продажу землі перетвориться у «дерибан».

Такий підхід забезпечить ефективне використання наявних земельних ресурсів, пожвавлення використання трудових, фінансових та інвестиційних ресурсів, зайнятості населення тощо. 


\section{Список використаної літератури:}

1. Meadows D.H. The Limits to Growth / D.H. Meadows. - New York : Potomac Associates, 1972 [Electronic Resourse]. - Access mode : http://www.clubofrome. org.ua/arkh-v/dopov-d-na-m-zhnarodnomu-sem-nar.html.

2. Економічні проблеми використання в Україні землі як стратегічного ресурсу / Б.М. Андрушків, Г.М. Тарасюк, Ю.О. Ульянченко та ін. // Державне будівництво. - Харківський регіональний ін-т держ. управління Нац. академії держ. управління при Президентові України. - 2015. - № 1 [Електронний pecypc]. - Режим доступу : http://www.kbuapa.kharkov.ua/e-book/db/2015-1/doc/2/02.pdf.

3. Земля як стратегічний продукт, об'єкт оренди та можливий еквівалент обміну в умовах застосування інноваційно-логістичних підходів може посилити економічні позиції України в СС / Б.М. Андрушків, Н.Б. Кирич, О.Б. Погайдак та ін. // Вісник Житомирського державного технологічного університету. Серія : Економічні науки. - 2013. - № 4. - С. 132-144 [Електронний ресурс]. - Режим доступу : http://nbuv.gov.ua/UJRN/Vzhdtu_econ_2013_4_17.

4. Інноваційні підходи до раціонального і ефективного використання природніх ресурсів / Б.М. Андрушків, Ю.Я. Вовк, В.А. Паляниия, О.Б. Погайдак // Інноваційна економіка. - 2012. - № 1. - С. 13-18.

5. Ресурсономіка: теоретичні та прикладні аспекти / Б.М. Андрушків, Ю.Я. Вовк, І.П. Вовк та ін. - Тернопіль : Терно-граф, 2012. - 456 с

6. Вовк Ю.Я. Вплив факторів ресурсоємності продукції на ефективність виробництва у машинобудівній галузі / Я.Ю. Вовк, Б.О. Погайдак // Збірник тез доповідей наукової конференції Тернопільського національного технічного університету імені Івана Пулюя, 14-15 грудня 2011 року. - Тернопіль : ТНТУ, 2011 - С. 216.

7. Вовк Ю.Я. Організаційно-економічний механізм управління раціональним використанням ресурсів / Я.Ю. Вовк // Соціально-економічні проблеми і держава. - 2011. - Вип. 1 (4) [Електронний ресурс]. - Режим доступу : http://sepd.tntu.edu.ua/images/stories/pdf/2011/11vyyrvr.pdf.

8. Мазін Ю.О. Економічні основи управління інноваційною ресурсозберігаючою політикою в машинобудуванні / Ю.О. Мазін. - Суми : СДУ, 2005. - 222 с.

9. Мочерний С.B. Методологія економічного дослідження / C.B. Мочерний. - Львів : Світ, 2001. -415 с.

10. А. с. № 37883. Ресурсономіка - новітня наука в системі виживання людства / Б.Н. Андрушків, Н.Б. Кирич, I.I. Стойко, І.П. Вовк, Ю.Я. Вовк. - опуб. 11.04.2011.

11. Умови ведення агробізнесу : земельні питання станом на 01.01.18 р. [Електронний ресурс]. - Режим доступу : http://ucab.ua/ua/doing_agribusiness/umovi_vedennya_agrobiznesu/zemelni_pitannya.

12. Экономика ресурсосбережения / под ред. А.М. Невелева. - К. : Наук. думка, 1989. - 248 с.

\section{References:}

1. Meadows, D.H. (1972), The Limits to Growth, Potomac Associates, New York, [Online], available at: http://www.clubofrome. org.ua/arkh-v/dopov-d-na-m-zhnarodnomu-sem-nar.html

2. Andrushkiv, B.M., Tarasjuk, G.M., Ul'janchenko, Ju.O. and ofhers (2015), «Ekonomichni problemy vykorystannja v Ukrai'ni zemli jak strategichnogo resursu», Derzhavne budivnyctvo, No. 1, [Online], available at: http://www.kbuapa.kharkov.ua/e-book/db/2015-1/doc/2/02.pdf

3. Andrushkiv, B.M., Kyrych, N.B, Pogajdak, O.B. and others (2013), «Zemlja jak strategichnyj produkt, ob’jekt orendy ta mozhlyvyj ekvivalent obminu $\mathrm{v}$ umovah zastosuvannja innovacijno-logistychnyh pidhodiv mozhe posylyty ekonomichni pozycii' Ukrai'ny v JeS», Visnyk Zhytomyrs'kogo derzhavnogo tehnologichnogo universytetu, Serija Ekonomichni nauky, No. 4, pp. 132-144, [Online], available at: http://nbuv.gov.ua/UJRN/Vzhdtu_econ_2013_4_17

4. Andrushkiv, B.M., Vovk, Ju.Ja., Paljanycja, V.A. and ofhers (2012), «Innovacijni pidhody do racional'nogo i efektyvnogo vykorystannja pryrodnih resursiv», Innovacijna ekonomika, No. 1, pp. 13-18.

5. Andrushkiv, B.M., Vovk, Ju.Ja. and Vovk, I.P. (2012), Resursonomika: teoretychni ta prykladni aspekty, Ternograf, Ternopil', $456 \mathrm{p}$.

6. Vovk, Ju.Ja. and Pogajdak, B.O. (2011), «Vplyv faktoriv resursojemnosti produkcii' na efektyvnist' vyrobnyctva u mashynobudivnij galuzi», Zbirnyk tez dopovidej naukovoi' konferencii' Ternopil's'kogo nacional'nogo tehnichnogo universytetu imeni Ivana Puljuja, 14-15 grud., Ternopil', p. 216.

7. Vovk, Ju.Ja. (2011), «Organizacijno-ekonomichnyj mehanizm upravlinnja racional'nym vykorystannjam resursiv», Social'no-ekonomichni problemy $i$ derzhava, Issue 1 (4), [Online], available at: http://sepd.tntu.edu.ua/images/stories/pdf/2011/11vyyrvr.pdf

8. Mazin, Ju.O. (2005), Ekonomichni osnovy upravlinnja innovacijnoju resursozberigajuchoju politykoju $v$ mashynobuduvanni, SDU, Sumy, $222 \mathrm{p}$.

9. Mochernyj, S.V.( 2001), Metodologija ekonomichnogo doslidzhennja, Svit, L'viv, 415 p.

10. Andrushkiv, B.N., Kyrych, N.B., Stojko, I.I., Vovk, I.P. and Vovk, Ju.Ja. (2011), Resursonomika - novitnja nauka v systemi vyzhyvannja ljudstva, UA., A. s. No. 37883.

11. Ukrai'ns'kyj klub agrarnogo biznesu (2018), «Zemel'ni pytannja stanom na 01.01.18 r.», Umovy vedennja agrobiznesu, [Online], available http://ucab.ua/ua/doing_agribusiness/umovi_vedennya_agrobiznesu/zemelni_pitannya

12. Nevelev, A.M. (ed.) (1989), Jekonomika resursosberezhenija, Nauk. dumka, Kyi'v. 248 p. 
Андрушків Богдан Миколайович - доктор економічних наук, професор, заслужений діяч науки і техніки України, завідувач кафедри управління інноваційної діяльності та сферою послуг Тернопільського національного технічного університету імені Івана Пулюя.

Наукові інтереси:

- стратегічне управління інноваційним розвитком підприємств;

- проблеми теорії і практики менеджменту;

- антикризове управління в малому бізнесі.

E-mail: andrushkiv.bohdan@gmail.com.

Тарасюк Галина Миколаївна - доктор економічних наук, професор, декан факультету бізнесу та сфери обслуговування Державного університету «Житомирська політехніка».

Наукові інтереси:

- проблеми теорії та практики менеджменту суб’єктів господарювання;

- управління проектами;

- продовольча проблема та інноваційний розвиток харчової індустрії.

E-mail: galinatar@ukr.net.

Кирич Наталя Богданівна - доктор економічних наук, професор, завідувач кафедри менеджменту та адміністрування Тернопільського національного технічного університету імені Івана Пулюя.

Наукові інтереси:

- проблеми теорії та практики менеджменту суб’єктів господарювання;

- дослідження сучасного стану переробної галузі агропромислового комплексу в Україні та встановлення напрямів її вдосконалення.

E-mail: nkuruch@gmail.com.

Ульянченко Юрій Олександрович - доктор наук 3 державного управління, доцент кафедри економічної політики та менеджменту Національної академії державного управління при Президентові України (м. Харків).

Наукові інтереси:

- механізми ефективного розвитку економіки аграрної сфери України.

Пешко Анатолій Володимирович - доктор економічних наук, підприємець в аграрній сфері та сфері енергоресурсів.

Наукові інтереси:

- механізми ефективного розвитку економіки аграрної сфери України.

Погайдак Ольга Богданівна - доктор економічних наук, старший науковий співробітник Тернопільського національного технічного університету імені Івана Пулюя.

Наукові інтереси:

- проблеми теорії та практики менеджменту суб'єктів господарювання;

- дослідження сучасного стану переробної галузі агропромислового комплексу в Україні та встановлення напрямів її вдосконалення.

Стаття надійшла до редакції 18.09.2019. 